\title{
Unilateral Pseudotumor Orbita in a 13-year-old Boy
}

\section{On Üç Yaşında Bir Çocukta Unilateral Psödotümör Orbita}

\author{
Damla Yıldız'(iD), Rumeysa Yalçınkaya²(ID), Türkan Aydın Teke²(iD), Fatma Nur Öz²(iD), Ayşe Kaman²(iD), \\ Sevgi Yaşar Durmuş²(ID), Yasemin Taşcı Yıldız(iD), Gönül Tanı²(ID) \\ 1 Department of Pediatrics, Dr. Sami Ulus Maternity and Children's Health and Diseases Training and Research Hospital, Ankara, Turkey \\ ${ }^{2}$ Department of Pediatric Infectious Diseases, Dr. Sami Ulus Maternity and Children's Health and Diseases Training and Research Hospital, Ankara, Turkey \\ ${ }^{3}$ Department of Radiology, Dr. Sami Ulus Gynecology, Maternity and Children's Health and Diseases and Research Hospital, Ankara, Turkey
}

Cite this article as: Yıldız D, Yalçınkaya R, Aydın Teke T, Öz FN, Kaman A, Yaşar Durmuş S, et al. Unilateral pseudotumor orbita in a 13-year-old boy. J Pediatr Inf 2021;15(2):e115-e118.

\section{Abstract}

Orbital pseudotumor (idiopathic orbital inflammation) is a clinical syndrome, in which the etiology or pathogenesis are unknown. It is rarely seen in the childhood. Clinical findings are usually acute onset, and include eye pain, periorbital edema, redness, and limitation of eye movements. Diagnosis is based on clinical and radiological findings. Orbital cellulitis, malignancies, rheumatological diseases and orbital trauma should be considered in differential diagnosis. Corticosteroids are used in treatment, and response to treatment is usually rapid. In cases that do not respond to corticosteroid therapy, radiotherapy or immunosuppressive therapy can be applied. Herein, we to present a 13-year-old boy who was referred to our hospital after unsuccessful oral antibiotic treatment at another institution with a preliminary diagnosis of orbital cellulitis due to edema and redness in the orbita. Orbital pseudotumor should be kept in mind in cases unresponsive to antibiotic treatment for preseptal/ orbital cellulitis.

Keywords: Eye pain, inflammation, orbital cellulitis, proptosis, orbital pseudotumor

\section{Introduction}

Orbital pseudotumor (idiopathic orbital inflammatory disease) is a benign, noninfective and non-neoplastic clinical syndrome (1). It is rarely seen in the childhood and can be con-
Öz

Psödotümör orbita (idiyopatik orbital inflamasyon), etiyolojisi ve patogenezi tam olarak bilinmeyen bir klinik sendromdur. Çocukluk çağında nadir olarak görülür. Klinik bulgular genellikle akut başlangıçıdır ve göz ağrısı, periorbital ödem, kızarıklık, göz hareketlerinde kısıtlılık görülebilir. Tanı, klinik ve radyolojik olarak konulur. Ayırıcı tanıda orbital selülit, maligniteler, romatolojik hastalıklar ve orbital travma düşünülmelidir. Tedavide kortikosteroidler kullanılır ve tedaviye yanıt genellikle hızlıdır. Kortikosteroid tedavisine yanıt vermeyen vakalarda radyoterapi veya immünsüpresif tedavi uygulanabilir. Burada, sol gözde şişlik ve kızarıklık nedeniyle dış merkeze başvuran, orbital selülit tanısı ile oral antibiyotik tedavisi uygulanan ve şikayetlerinde gerileme olmayınca hastanemize sevk edilen 13 yaşında bir erkek olgu sunulmuştur. Preseptal/orbital selülit nedeniyle başlanan antibiyotik tedavisine yanıt vermeyen hastalarda psödotümör orbita tanısı akılda tutulmalıdır.

Anahtar Kelimeler: Gözde ağrı, inflamasyon, orbital selülit, proptozis, psödotümör orbita

fused with preseptal or orbital cellulitis since they are clinically similar. Patients mainly present with pain, periorbital edema, proptosis, diplopia and rarely, loss of vision (2). Despite usually being unilateral, there are studies reporting bilateral cases

Correspondence Address / Yazışma Adresi

Rumeysa Yalçınkaya

Ankara Dr. Sami Ulus Kadın Doğum Çocuk Sağlığı ve Hastalıkları

Eğitim ve Araştırma Hastanesi,

Çocuk Enfeksiyon Hastalıkları Kliniği,

Ankara-Türkiye

E-mail: rumeysa_ra@hotmail.com 
may occur. Diagnosis is generally made by meticulous history, clinical findings and imaging methods. Early diagnosis is necessary to prevent retinal and extraocular muscle damage (3).

Herein, we present a case of a 13-year-old boy in whom steroid treatment was started for idiopathic orbital inflammatory disease upon seeing that the patient had not responded to the antibiotic treatment given for preseptal cellulitis diagnosis. The patient rapidly responded to the steroid treatment.

\section{Case Report}

A 13-year-old boy presented with swelling, pain and redness in the left eye which were present for seven days. The patient was referred to our hospital when his complaints did not regress despite treatment with tobramycin containing eye drops and and oral amoxicillin clavulanic acid ( $2 \times 1 \mathrm{~g})$ prescribed for the preliminary diagnosis of preseptal cellulitis. On admission, Physical examination showed that his general status was good, body temperature and other vital signs were normal (Figure 1). His visual acuity was normal, the vision in both eyes was complete, and light reflex response was normal. There was no relative afferent papillary defect. Laboratory findings were as follows: white blood cell count $7300 / \mathrm{mm}^{3}$ (72\% polymorpho-

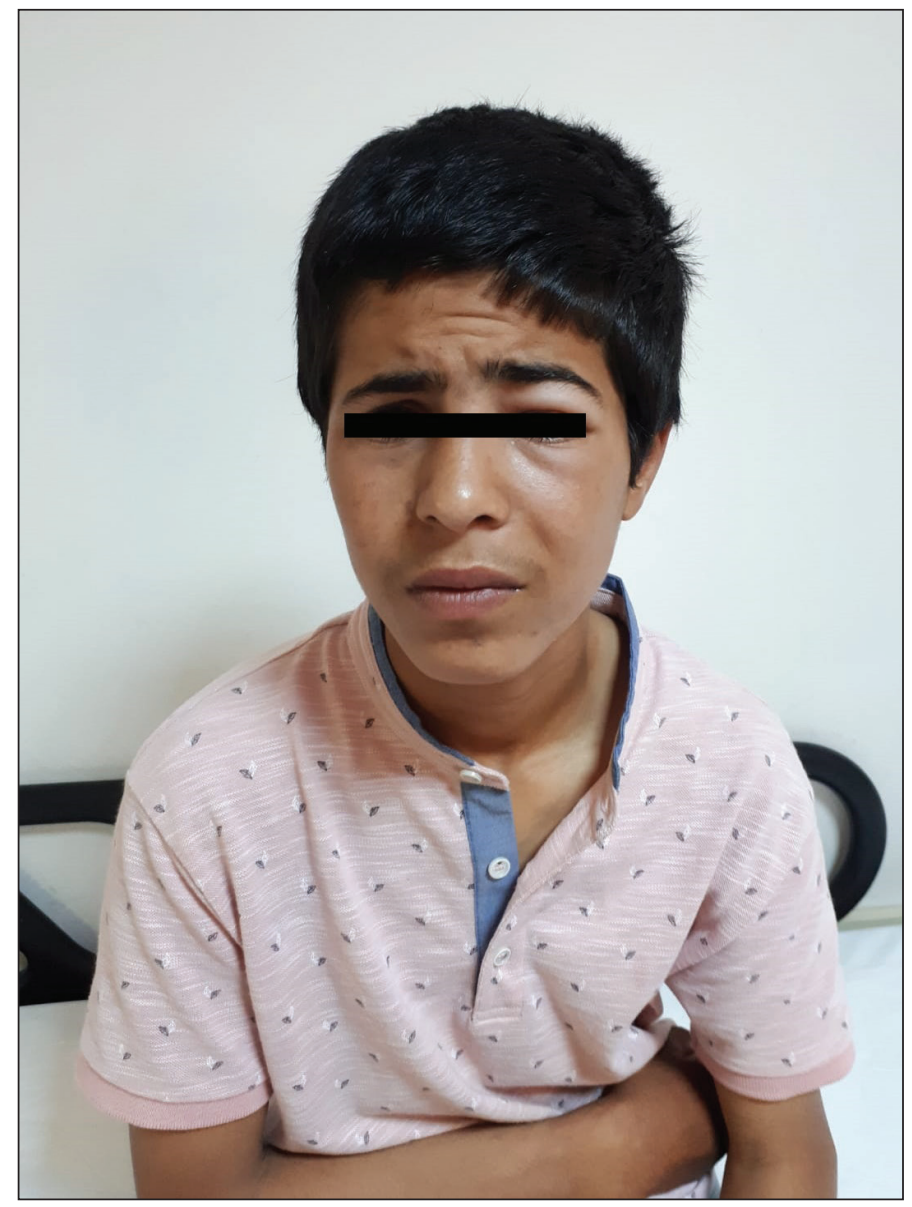

Figure 1. Proptosis in the left eye, periorbital edema. nuclear, $18 \%$ lymphomonocytes), hemoglobin $13.5 \mathrm{~g} / \mathrm{dl}$, and platelet count $224.000 / \mathrm{mm}^{3}$. His biochemical parameters were normal, and C-reactive protein (CRP), erythrocyte sedimentation rate (ESR), and anti-streptolysin-O (ASO) were found respectively as $3.14 \mathrm{mg} / \mathrm{L}, 30 \mathrm{~mm} / \mathrm{h}$, and $1040 \mathrm{IU} / \mathrm{L}$. Orbital computed tomography (CT) showed preseptal space was edematous in the left eye, obliteration of the retrobulbar fat planes were obliterated, and left lacrimal gland and lateral rectus muscle were hypertrophic and dense (Figure 2). Orbital magnetic resonance imaging (MRI) revealed thick and edematous preseptal space, increased thickness of the left lateral rectus muscle, common T2 intensity increase and contrast-enhanced retrobulbar and postseptal fat planes (Figure 3). The findings were significant form the diagnosis of idiopathic orbital inflammation/orbital pseudotumor. On the fifth day of the sulbactam ampicillin (8 $\mathrm{gr} /$ day) treatment intravenous prednisolone treatment $(2 \mathrm{mg} /$ $\mathrm{kg} /$ day) was commenced for three days. The patient whose eye complaints remarkably ameliorated on the second day of steroid treatment (Figure 4) was discharged provided that he

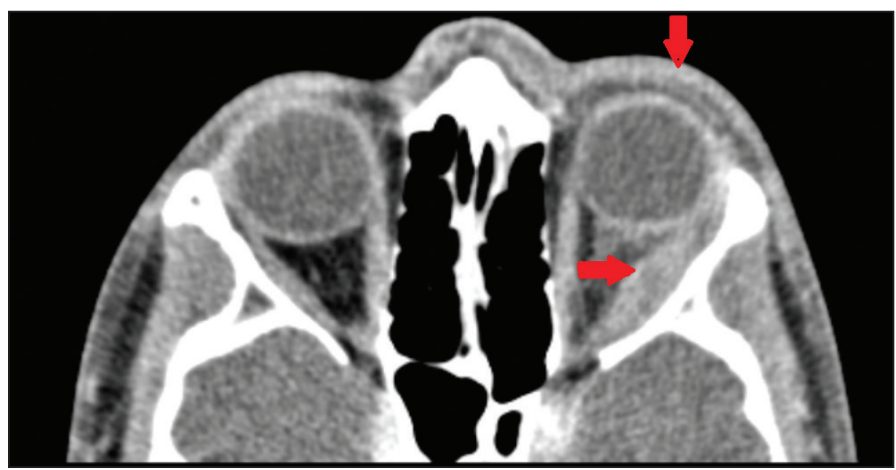

Figure 2. CT scan, hypertrophy in the left lateral rectus muscle and edema in the left preseptal distance.

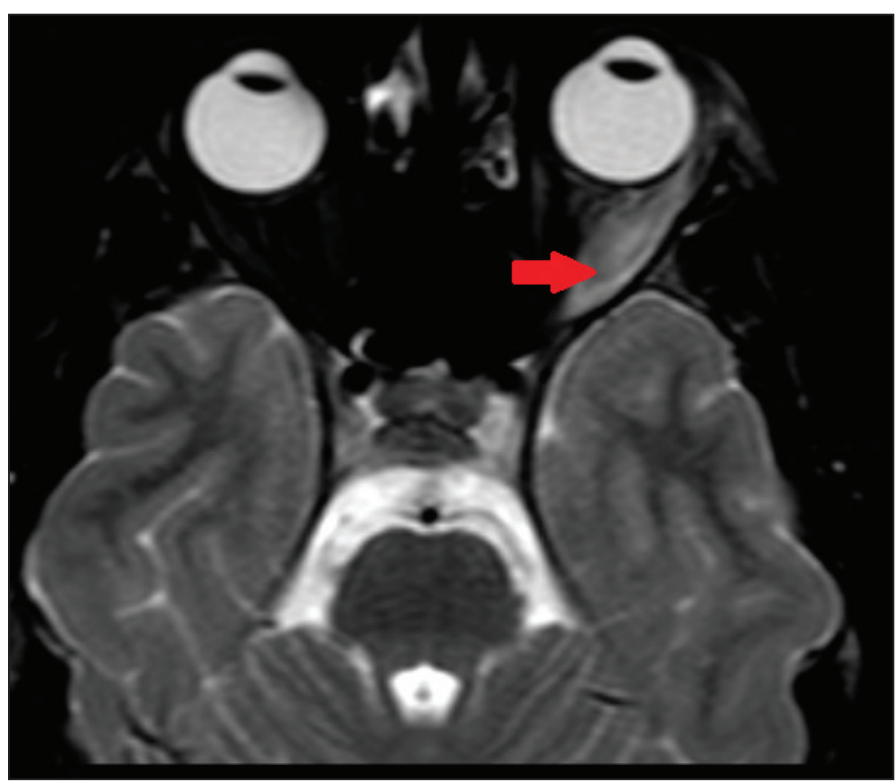

Figure 3. Axial MRI scan, marked hypertrophy in the left rectus muscle. 


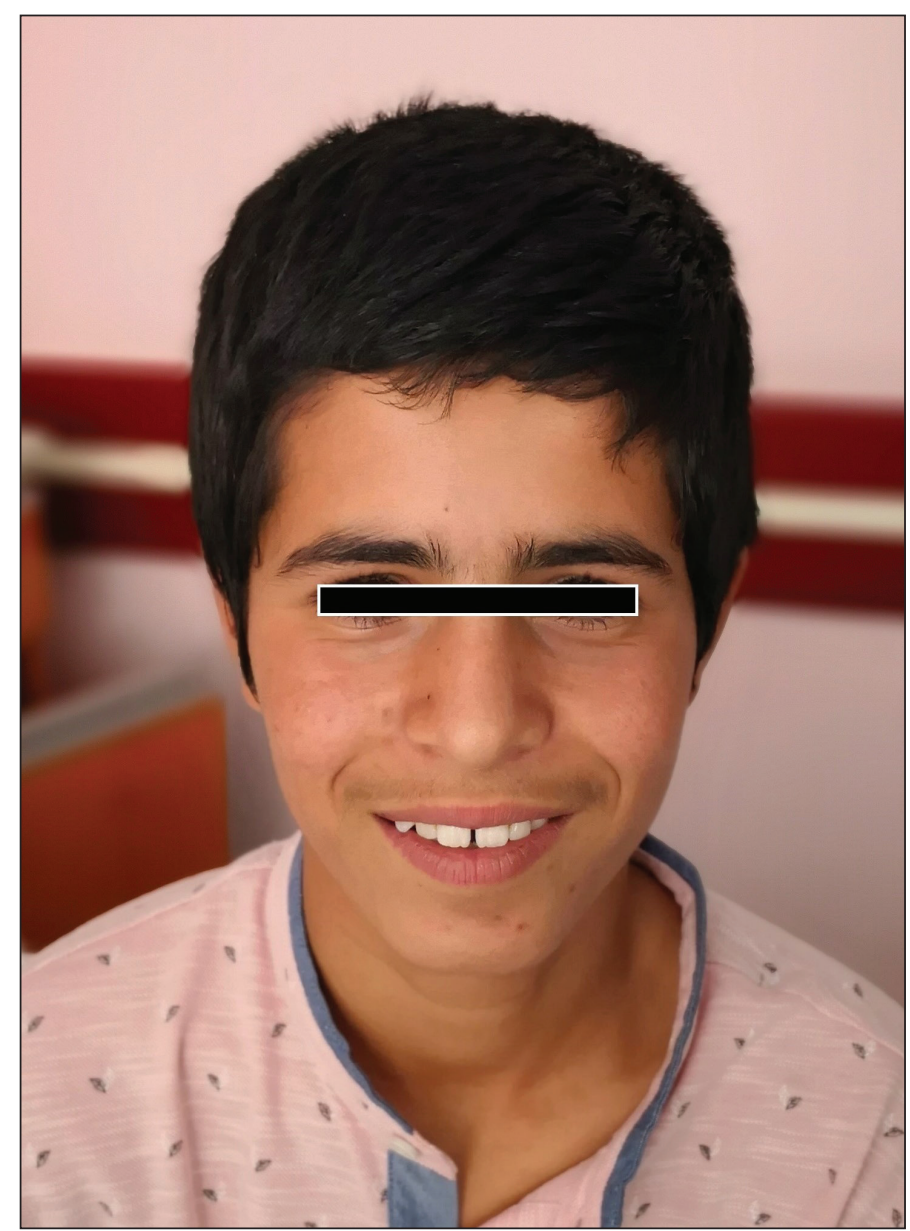

Figure 4. Regression in findings following intravenous steroid treatment.

would come to follow-ups during a total of 6-week oral prednisolone treatment. Investigation for etiological causes revealed that thyroid function tests (TFT), C3-C4, rheumatoid factor, lgG4 level and angiotensin converting enzyme (ACE) were detected normal. Anti-neutrophil cytoplasmic antibodies (c-ANCA and p-ANCA), antiphospholipid antibody, anticardiolipin antibody, and anti-ds DNA antibodies were negative. On the follow-up after discharge, it was seen that the eye findings of the patient regressed completely. Oral consent was received from the patient's family to use and publish his photographs.

\section{Discussion}

Idiopathic orbital inflammatory disease, which is rarely seen in the pediatric population, is among the most common reasons of exophthalmos. Clinical presentation usually includes pain, proptosis, periorbital swelling, decrease in visual acuity, and limitation in eye movements. It is typically an acute-onset disease, generally unilateral, and rarely bilateral. Headache, vomiting, and weight loss can be frequently seen in children $(1,4)$. At the beginning, our patient was considered to have orbital cellulitis due to periorbital swelling, pain and limitation in his eye movements, and antibiotic treatment was initiated. His sy- mptoms and examination findings completely resolved after the steroid treatment. No underlying reason was detected during the investigation for etiology.

The etiology of orbital pseudotumor is not fully known, and it is considered that immune-related processes, infections, and autoimmune diseases can be responsible for the disease. It has been thought that trauma may cause increased vascular permeability, which may lead to the release of antigenic substrates that can activate inflammatory cascade. Some of the diseases to be considered in differential diagnosis are thyroid ophthalmopathy, orbital vasculitis, Wegener granulomatosis, sarcoidosis, lymphoma, leukemia, rhabdomyosarcoma, lymphangioma, neuroblastoma, Langerhans cell histiocytosis, secondary orbital retinoblastoma, foreign object-related orbital trauma, and ruptured dermoid cyst (5-7). Orbital pseudotumor can develop following viral upper respiratory tract infection, streptococcal pharyngitis, and sinusitis. A new onset orbital myositis case two weeks after streptococcal pharyngitis has been reported in the literature (8). In a study conducted in China including 209 patients diagnosed with orbital pseudotumor in a period of 20 years, sinusitis has been confirmed in 36 (17.2\%) of these cases (9). History or physical examination finding supportive of upper respiratory tract infection was not detected in our patient.

Orbital pseudotumor can be associated with rheumatologic diseases such as Chrohn's disease, systemic lupus erythematosus (SLE), rheumatoid arthritis (RA), myasthenia gravis (MG), and ankylosing spondylitis (10). Due to the association between orbital pseudotumor and rheumatologic diseases, suspected cases must undergo tests including complete blood count, ESR, CRP, thyroid function tests, ACE level, p-ANCA and c-ANCA (10). In our patient, no underlying reason was detected during the investigation for etiology.

On MRI and CT imaging of orbital myositis, a thickening appearance showing unilateral fusiform configuration and involving one or more extraocular muscle and myotendinous component is seen. Infiltrative appearance can be seen along the surrounding orbital fat tissue. Lacrimal gland is evidently enlarged, and a marked enlargement can also be seen along the lateral orbital wall and lateral rectus muscle. Thickening can be seen in extraocular muscles (single or multiple). The most commonly involved muscle is the medial rectus muscle and is followed by superior rectus, lateral rectus, and inferior rectus muscles. There may be infiltrates that cause a dirty appearance throughout the orbital fat at the edge of the muscle. Inflammatory tissues surrounding the optic nerve may cause the typical tram line appearance (5). Similar findings can be observed in thyroid ophthalmopathy; however, extraocular muscles are bilaterally affected. Thyroid ophthalmopathy was not considered in our patient since he had unilateral extraocular muscle 
involvement and a normal TFT. Left-sided lateral rectus muscle hypertrophy, intensity elevation in retrobulbar fat planes, and edema in left preseptal distance were the imaging findings that led us to diagnose the patient with idiopathic orbital inflammatory disease (Figure 3,4).

Systemic corticosteroids are first-line therapies in treatment. Rapid response to steroid treatment supports diagnosis (11). Initial dosage is $1 \mathrm{mg} / \mathrm{kg} /$ day prednisone and is terminated by lowering the dosage in 6-8 weeks. Long-term steroid use may have side effects such as hyperglycemia, hypertension, cushingoid appearance, osteoporosis, adrenal suspension, weight gain, avascular bone necrosis, and growth retardation. Ocular side effects include glaucoma, cataract, and herpetic corneal infection $(5,12)$. Oral non-steroid anti-inflammatory drugs (NSAI) can be used in the treatment of mild idiopathic orbital inflammation. Noble and colleagues have given indomethacin treatment to an orbital myositis patient that developed side effects against corticosteroid treatment and become successful in treatment (13). Mannor and colleagues have recommended NSAI use for three weeks or until complete recovery in clinical findings is achieved in orbital pseudotumor cases (14). Low dose radiotherapy may be used in patients who do not respond to and are contraindicated to corticosteroids and in recurrent cases. Immunosuppressive treatment, chemotherapy, and intravenous immunoglobulin (IVIG) may also be used in some situations $(10,15,16)$. Our patient did not require any additional treatment since the pain in his eye and proptosis regressed on the second day of corticosteroid treatment and a marked improvement was observed in his findings on the fifth day of the treatment.

\section{Conclusion}

Orbital pseudotumor is a rarely seen disease in the childhood. It must be considered in the differential diagnosis of preseptal/orbital cellulitis, should be specifically kept in mind in patients with proptosis and in those with weak response to the antibiotic treatment started for preseptal cellulitis, and diagnosis must be supported with imaging methods.

Informed Consent: Patient consent was obtained.

Peer-review: Externally peer-reviewed.

Author Contributions: Concept -RY, DY, TAT; Design - DY, RY, GT, FNO; Supervision - RY, FNO, TAT, GT; Resources - All of authors; Data Collection and/or Processing - All of authors; Analysis and/ or Interpretation - RY, FNO, TAT; Literature Review - DY, RY, SYD, AK; Writing - DY, RY, FT; Critical Review - RY, GT.
Conflict of Interest: No conflict of interest was declared by the authors.

Financial Disclosure: The authors declared that this study has received no financial support.

\section{References}

1. Yuen SJ, Rubin PA. Idiopathic orbital inflammation: distribution, clinical features, and treatment outcome. Arch Ophthalmol 2003;121(4):491-9. [CrossRef]

2. Spindle J, Tang SX, Davies B, Wladis EJ, Piozzi E, Pellegrini $M$, et al. Pediatric idiopathic orbital inflammation: clinical features of 30 cases. Ophthalmic Plast Reconstr Surg 2016;32(4):270-4. [CrossRef]

3. Shehibo A, Admassu F, Bekele T, Solomon M, Solomon L, Gordon DM. Bilateral orbital pseudotumor in a 3-year-old child: a case report. J Trop Pediatr 2018;64(3):241-4. [CrossRef]

4. LeBedis CA, Sakai O. Nontraumatic orbital conditions: diagnosis with $C T$ and MR imaging in the emergent setting. Radiographics 2008;28(6):1741-53. [CrossRef]

5. Yesiltas YS, Gunduz AK. Idiopathic orbital inflammation: review of literature and new advances. Middle East Afr J Ophthalmol 2018;25(2):71-80. [CrossRef]

6. Bakan S, Bakan AA, Cingu AK, Beker Acay M, Gocmez A, Elbeyli A, et al. Myositic type of idiopathic orbital pseudotumor in a 4-year-old child: a case report. Case Rep Med 2012;2012:473856. [CrossRef]

7. Mottow-Lippa L, Jakobiec FA, Smith M. Idiopathic inflammatory orbital pseudotumor in childhood. II. Results of diagnostic tests and biopsies. Ophthalmology 1981;88(6):565-74. [CrossRef]

8. Purcell JJ, Taulbee WA. Orbital myositis after upper respiratory tract infection. Arch Ophthalmol 1981;99(3):437-8. [CrossRef]

9. Yan J, Wu Z, Li Y. 36 case idiopathic orbital inflammatory pseudotumor with sinus involvement. Lin Chuang Er Bi Yan Hou Ke Za Zhi 2002;16(8):410-1. [CrossRef]

10. Chaudhry IA, Shamsi FA, Arat YO, Riley FC. Orbital pseudotumor: distinct diagnostic features and management. Middle East Afr J Ophthalmol 2008;15(1):17-27. [CrossRef]

11. Guerriero S, Di Leo E, Piscitelli D, Ciraci L, Vacca A, Sborgia C, et al. Orbital pseudotumor in a child: diagnostic implications and treatment strategies. Clin Exp Med 2011;11(1):61-3. [CrossRef]

12. Harris GJ. Idiopathic orbital inflammation: a pathogenetic construct and treatment strategy: The 2005 ASOPRS Foundation Lecture. Ophthalmic Plast Reconstr Surg 2006;22(2):79-86. [CrossRef]

13. Noble AG, Tripathi $R C$, Levine RA. Indomethacin for the treatment of idiopathic orbital myositis. Am J Ophthalmol 1989;108(3):336-8. [CrossRef]

14. Mannor GE, Rose GE, Moseley IF, Wright JE. Outcome of orbital myositis. Clinical features associated with recurrence. Ophthalmology 1997;104(3):409-13; discussion, 14. [CrossRef]

15. Espinoza GM. Orbitalinflammatorypseudotumors:etiology, differential diagnosis, and management. Curr Rheumatol Rep 2010;12(6):443-7. [CrossRef]

16. Gordon LK. Orbital inflammatory disease: a diagnostic and therapeutic challenge. Eye (Lond) 2006;20(10):1196-206. [CrossRef] 